\title{
Potentials for Commercial Production of Biogas from Domestic Food Waste Generated in Benin Metropolis, Nigeria
}

\author{
*1AKHATOR, EP ${ }^{\mathrm{a}}$; IGBINOMWANHIA, DI ${ }^{\mathrm{b}}$; OBANOR, AI \\ Mechanical Engineering Department, University of Benin, Benin City, Nigeria

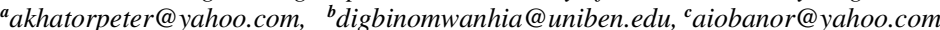 \\ Mechanical Engineering Department, University of Benin, Benin City, Nigeria \\ Corresponding Author: email: digbinomwanhia@uniben.edu,digbinomwanhia@yahoo.com
}

\begin{abstract}
The work reported in this paper investigated the potentials of commercial biogas production from biodegradable waste in Benin metropolis. The study was carried out in two phases. The first phase involved characterization of solid waste generated and determination of the quantity of potential feed stock for biogas production in Benin metropolis and the second phase was determination of the amount of biogas obtainable from biodegradable waste. The results from the study showed that an average daily generation rate of $0.358 \mathrm{~kg}$ per person per day (ppd.) of solid waste is generated in study area. Food waste accounted for about $78.49 \%$ of the generated solid waste representing $0.281 \mathrm{~kg}$ per person per day (ppd.) and a total daily food waste generation of 305.075tonnes. Based on this value for food waste the obtainable biogas was estimated to be $28,836.91 \mathrm{~m}^{3}$ of biogas in Benin metropolis per day. This volume of biogas can provide cooking gas for about 24,076.91 families per month in Benin metropolis or alternatively can be utilised to generate about $49.023 \mathrm{MW}$ of electricity per day. () JASEM
\end{abstract}

\section{http://dx.doi.org/10.4314/jasem.v20i2.19}

Keywords: $\quad$ Solid waste management, food waste, anaerobic digestion, biogas

\section{Introduction}

Rapid urbanization and population growth have led to increase solid waste generation in Benin metropolis and have magnified the necessity for adequate solid waste management in the metropolis. A study by Igbinomwanhia (2010) showed that waste typology in Benin metropolis varies and those unable to decompose become pollutant and create unsightly appearance in the environment (Ikelegbe and Ogeah, 2003). The Local Government Authorities saddled with the responsibility of waste management (Federal Ministry of Environment, 2005) have not been able to handle the amount of solid waste generated in the metropolis. Hence, indiscriminate dumping of refuse in street corners, by the road sides, medians of the road, in open spaces, around residential buildings or drainage systems is a common practice in the metropolis (Igbinomwanhia and Ohwovoriole, 2011). These practices do not only lead to unsightly look of the metropolis, but also to a high risk of air pollution and contamination of ground waters sources through leachate and promotes the breeding of rodents and disease vectors.

However, several policies have been formulated on waste management at the federal, state and local government levels. For example the policies at the state level provide the dumpsite option as the end point for solid waste in Edo state (Edo state, 2010). The formulation and implementation of such incoherent policies with respect to standard practice in the waste management sector has made solid waste management to be commonly seen in the metropolis as simply "pick up the waste and go dump it in the dumpsite" whether it is approved dumpsite or illegal dumpsite.

The solid waste management practice at the approved dumpsite is simple. The waste disposal trucks collect waste from household and business premises and transport them to the dumpsite. At the dumpsites the trucks drive in through the access roads and dump their waste. Other vehicles that deliver waste to the site simply dump their waste indiscriminately by the road sides after closing hour. The workers at the dumpsites use shovel to manually push the waste from the access road and try to spread them as much as their strength can go. Thereafter, open air incineration without pollution control is carried out on the waste for volume reduction. This is not sustainable as it does not bring financial return at the end point of the waste. Solid waste management has therefore become a nightmare to waste management decision makers in Benin metropolis. If a sustainable solid waste management must be actualized, integrated solid waste management system which ensures financial returns at the end point of the waste is the best option. Integrated solid waste management is a waste management mix that incorporates recycling, composting, incineration with energy recovery, anaerobic digestion for biogas production etc. The preliminary study of this work 
reveals that there is a high percentage of food waste in domestic waste in Benin metropolis. Food waste is high source for biogas production due to its high volatile solids (VS) content and high biodegradability (Zhang et al., 2007; Igoni et al., 2008). VS are the fractions of the food waste that can be biodegraded to produce biogas and hence are the ultimate source of methane (Curry et al., 2012; Bind and Templeton, 2011).

The work reported in this paper is therefore the study of the potential for commercial biogas production - an alternative waste management approach, which involves energy and nutrients recovery. If adequately harnessed, the organic fraction (food waste) of the solid waste generated in Benin metropolis could be converted to energy and nutrients via anaerobic digestion.

\section{MATERIALS AND METHODS}

The study was carried out in two phases: determination of the quantity of potential domestic feed stock for biogas production in Benin metropolis and determination of the amount of biogas obtainable from domestic biodegradable waste in Benin metropolis.

The first phase of the study involves the review of related literature, preliminary field work in the Benin metropolis and application of the site-specific study for the determination of the quantity of potential domestic feed stock for biogas production. The sitespecific study involved the following steps - selecting a representative sample, sample collection, sample analysis and the use of structured questionnaires to collect primary information such as size of households, income, educational level etc. from households. A multi-stage stratified random sampling method (Drew, 1980) was applied for the sampling process. Due to the largeness of the number of households, the study was broken down into three subsurveys made up of the three Local Government Areas (LGA) in the metropolis: Oredo, Egor and IkpobaOkha LGAs, fig. 1. These three Local Governments areas were then taken as geographical strata (Som, 1973). The geographical strata (local government areas) were further stratified into communities to form sub-strata and some sub-strata were randomly selected for the study. 250 households were then selected from the selected sub-strata in each geographical stratum. Each selected household was visited several times. In the first visit, contact was made and participation consent requested. Upon approval, a second visit was made to distribute questionnaires and moderate size bags for storing their solid waste over the following seven days. The next visits were made at regular intervals to collect the solid waste generated over seven days at each household.

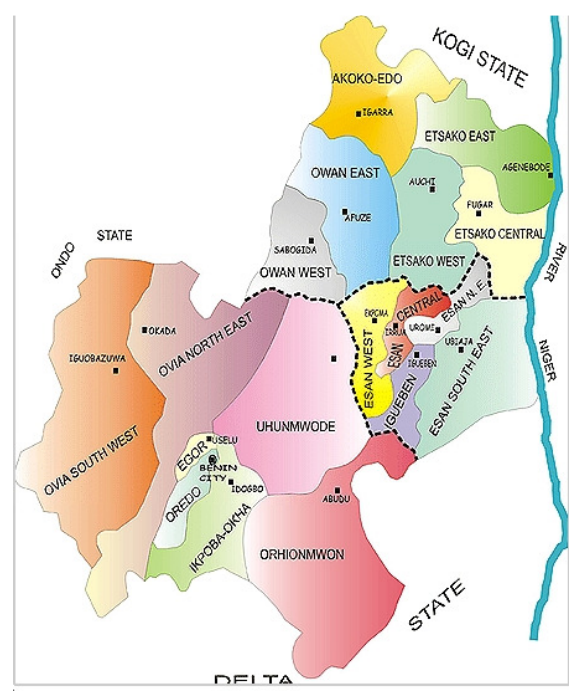

Fig 1: Map of Edo State showing Benin Metropolis (Edo State Government, 2007).

In the second phase of the work, determination of the amount of biogas obtainable from organic fraction of domestic solid waste (OFDSW) generated in Benin metropolis was carried out. This involved the determination of the total solid (TS) of the organic fraction of the domestic food waste (OFDFW), determination of the volatile solid (VS) and application of the value of the VS to determine the obtainable amount of biogas. The average value of TS is about $27.14 \%$ of OFDSW and the VS are about $94.90 \%$ of TS (Kigozi et al, 2014). The biogas production from OFDSW is about $367 \mathrm{~m}^{3} / \mathrm{tVS}$ (USEPA, 2008). These values were therefore applied in the basic theory equation given in equation (1) for the production of biogas from organic fraction of solid waste to determine the obtainable biogas from OFDSW in Benin metropolis.

Total biogas obtainable $=$ Amount of food waste $(\mathrm{t}) \times$ VS $(\%) \times$ Biogas yield $\left(\mathrm{m}^{3} / \mathrm{t}\right.$ VS) $(1)$

\section{RESULTS AND DISCUSSION}

Solid Waste Characterization: The waste generated in each selected household was collected at regular intervals of seven days, sorted and individual components were weighed and recorded. The data were further analyzed and the results from the analysis for households are shown in table 1. A total of $9788.39 \mathrm{~kg}$ (9.79 metric tons) of residential solid waste made up of $5373.61 \mathrm{~kg}$ from Oredo LGA, $2438.04 \mathrm{~kg}$ from Egor LGA and $1956.74 \mathrm{~kg}$ from Ikpoba-Okha LGA was measured. Based on this value an average 
daily generation rate of $0.358 \mathrm{~kg}$ per person per day (ppd.) was calculated for Benin metropolis. The value of food waste, the highest at about $78.49 \%$ consist mainly of vegetables and meal left-over and scraps associated with preparation of food compared favourably with domestic waste for some towns and cities in developing countries, such as Georgetown, Guyana in southern America with about $72.8 \%$ (Zavodska, 2003), Katmandu, Capital City of Nepal with about 70-80\% (Alam, 2006), Nsuka in Enugu state of Nigeria with about 56\% (Ogweleka, 2003) Gwadalajara, in Mexico with about 52.9\% (Gerardo, 2001) and Mumbai in Indian with about $70 \%$ (Beukering, 1996), (Sashi, 2003). The food waste content of residential waste is very high because of the heavy dependent on home prepared meals, When compared to the food waste found in the USA of about $12.7 \%$ (USEPA, 2009) the cultural difference stands out (Zavodska, 2003). The waste was collected from the household at intervals of seven day and it was observed that some of the waste especially scraps from meal preparation were already putrefying. This therefore indicates that value of food waste obtained may be less than the actual value of food waste of the samples collected.

Results of the waste characterization also revealed an average of $8.66 \%$ of plastic/rubber, $4.75 \%$ of paper/cardboard, $3.07 \%$ of metal, $2.23 \%$ of glass, $1.68 \%$ of nylon and $1.12 \%$ of textile.

Table 1: The average component of household solid waste generated per person per day in Benin metropolis.

\begin{tabular}{lll}
\hline Component & $\begin{array}{l}\text { Component }(\mathrm{kg}) / \\
\text { person/day }\end{array}$ & \%Component \\
\hline Food waste & 0.281 & 78.49 \\
Plastic/rubber & 0.031 & 8.66 \\
Paper/cardboard & 0.017 & 4.75 \\
Metal & 0.011 & 3.07 \\
Glass & 0.008 & 2.23 \\
Nylon & 0.006 & 1.68 \\
Textile & 0.004 & 1.12 \\
Total & 0.358 & 100 \\
\hline
\end{tabular}

The organic fraction of domestic solid waste (OFDSW) generated in Benin metropolis represents about $84.36 \%$ of the waste composition and consists of food waste, paper and textile. However, anaerobic digestion of paper and textile is slow and takes a long time for completion; hence it was not considered in this study. The high calorific and nutritive value of food wastes make them easily biodegradable by microbes and hence a rich source for biogas production. Food waste which makes up $78.49 \%$ of the solid waste generated per person per day translate to $0.281 \mathrm{~kg}$ per person per day. It comprises left over from meals (such as boiled yam, boiled plantain, boiled rice, boiled cassava products, boiled maize, bread crumbs, etc) and kitchen waste such as peelings from yam, cassava, and plantain. The high moisture content of these food wastes limits their disposal option to composting and anaerobic digestion as combusting wet waste stream does not provide much energy as most of the energy from its combustion is spent to reduce or eliminate the moisture content., composting consumes energy, requiring about $50-75 \mathrm{kWh}$ of electricity per ton of waste input (Agbo and Eze, 2011). While anaerobic digestion is a net energy producing process, with about $75-150 \mathrm{kWh}$ of electricity created per ton of waste input. Hence, the choice of anaerobic digestion for the disposal of food wastes.

Amount of Biogas Obtainable: From table 1, $0.281 \mathrm{~kg}$ of food waste is generated from domestic solid waste per person per day in Benin metropolis. With an estimated population of 1,085,676 (NPC, 2006), Benin metropolis witnesses a daily generation of about 305.075 tonnes of OFDSW (food waste). With TS of about $27.14 \%$, the OFDSW of 305.075 tonnes per day, will result in a TS of 82797.3 tonnes per day and VS of 78574.7 tonnes per day. Hence, with methane yield values of $367 \mathrm{~m}^{3} / \mathrm{tVS}$, a total of $28,836.91 \mathrm{~m}^{3}$ of biogas can be obtained from domestic food waste generated in Benin metropolis per day. This translates to $10,525,471.07 \mathrm{~m}^{3}$ per annum. This is almost $350 \%$ of the amount of biogas produced annually in Boras, Sweden (Taherzadeh, 2010).

In recent years many families in Benin metropolis have embraced the use of liquefied petroleum gas (LPG) for cooking due to its advantage with respect to kerosene. An average family in Benin metropolis consumes about $0.275333 \mathrm{~m}^{3}$ of LPG per day (Sadjere and Ariavie, 2001). The energy content of LPG is $26.1 \mathrm{kWh} / \mathrm{m}^{3}$ (Eriksson, 2010); hence an average family would need $7.1862 \mathrm{kWh}$ of energy for cooking per day. The energy content of biogas is $6 \mathrm{kWh} / \mathrm{m}^{3}$ (Eriksson, 2010); this implies that $173,021.5 \mathrm{kWh}$ will be available from the obtainable biogas. This translates into cooking energy for about 24,076.91 families per day in Benin metropolis. In addition $1 \mathrm{~m}^{3}$ of biogas can be converted to about $1.7 \mathrm{~kW}$ of electricity (Eriksson, 2010); therefore the obtainable biogas of $28,836.91 \mathrm{~m}^{3}$ would yield about $49.023 \mathrm{MW}$ of electricity per day.

Conclusion:The study revealed that about 305.075 tonnes/day of food waste is generated in Benin metropolis. This is sufficient for the production of about $28,836.91 \mathrm{~m}^{3}$ of biogas per day in Benin metropolis. This quantity of biogas can satisfy the 
cooking energy need of about 24,076.91 families per day. Alternately the quantity of biogas could be converted to about 49.023MW of electricity per day. In addition the effluent will provide good source of manure for agriculture. This therefore implies that commercial biogas production is feasible in Benin metropolis in Nigeria. Hence anaerobic digestion technology should be viewed as a waste management practice that should be incorporated in the waste management system in Benin metropolis.

\section{REFERENCES}

Agbo, K.E., and Eze, J.I. (2011). Anaerobic digestion of municipal solid waste for generation of energy: prospects and challenges in Nigeria. Nigeria Journal of Solar Energy, 22: 130-137.

Alam, R. Chowdhury, M.A.I, Hasan, G.M.J, Karanjit, B., Srestha, L.R. (2006): Solid waste management in Katmandu, Capital City of Nepal. Journal of Solid Waste Technology and Management Department of Civil Engineering

Beukering, P. Van, Sarka, M., Gerlagh, R., Kumar, V. (1999). Analysing Urban Solid waste in developing countries; a perspective on Bangalore, India. CREED working paper series, No. 24, IIED, London and Institute for Environment Studies, Amsterdam

Curry, N., and Pillar, P. (2012). Biogas Prediction and design of food waste to Energy System for the urban environment. Renewable Energy, 41: 200209.

Edo State (2010): Edo state sanitation and pollution law. Edo state law No. 5 of 2010.

Edo State Government. (2007). Map of Edo State. Available at www.edostate.gov.ng/search/node/map. (Accessed on November/28/2014).

Eriksson, O. (2010). Environmental Technology Assessment of Natural Gas Compared to Biogas, Natural Gas, Primoz Potocnik (Ed), ISBN: 978953-307-112-1, In Tech. Available at http://www.intechopen.com/books/naturalgas/environmental-technology- assessment-ofnatural-gas-compared-to-biogas. (Accessed on June/25/2015).

Federal Ministry of Environment (2005): policy guideline on solid waste management, Federal Republic of Nigeria.
Gerardo, B., Et al (2001): Solid Waste Characterisation Study in Guadalajara Metropolitan Zone, Mexico. Waste Management and Research, UK.

Igbinomwanhia, D.I (2010): Characterization Residential Solid Waste In Benin Metropolis, Nigeria. International Journal of Engineering, Indian, Vol. 4, No. 4 (479-486

Igbinomwanhia, D.I. and E.N Ohwovoriole (2011) A Study of the Solid Waste Chain in Benin Metropolis, Nigeria. Journal of Applied Sciences and Environmental Management, University Of Port Harcourt, 15 (4): 589 - 593.

Igoni, A.H., Abowei, M.F, Ayotamuno, M.J., and Eze, C.L. (2008). Effect of total solids concentration of municipal solid waste on the biogas produced in an anaerobic continuous digester. Agricultural Engineering International: The CIGR Ejournal. Manuiscript EE 07 010. Vol. X.

Ikelegbe, O.O and Ogeah, F.N. (2003). Perception and response to the challenges of environmental sanitation problems in Benin City and its environs. Benin Journal of Social Science, 12(2), Dec. 2003.

International Energy Agency (IEA) (1997). Systems and market overview of anaerobic digestion. IEA Bioenergy Anaerobic Digestion Activity Report. Available at www.ns.ist.cmu.ac.th/riseat/documents/adre view.pdf. Accessed on 25/06/2015.

Kigozi, R., Aboyade, A.O. and Muzenda, E. (2014). Sizing of an anaerobic digester for the organic fraction of municipal solid waste. World Congress on Engineering and Computer Science, San Francisco, USA, 2: 22-24

Ogweleka, T.C. (2003). Analysis urban solid waste in Nsuka, Nigeria. The journal of Solid Waste technology and Management, Department of Civil Engineering Widener University, Chester, U.S.A, 29(4).

Sadjere, E.G and Ariavie, G.O (2012). Determination of electrical energy equivalent of a typical household in the Niger Delta region of Nigeria. International Journal of Academic Research, Vol. 4, No. 3 May 2012.

Sashi, S. (2003). The Urban solid waste management problem in India: An economic approach 
and frame work for policy. Journal of solid waste technology and management, 29 (1).

Som, R.K. (1973): A manual of sampling Technique, Heinemann Education books, London

Taherzadeh, M. (2010). Energy generation from waste: A collaboration subject between Sweden and Nigeria.

A proceeding of the annual congress of Nigerian Academy of Engineering.

USEPA (2008) East Bay Municipal Utility District, "Anaerobic Digestion of Food Waste," U.S.

ENVIRONMENTAL PROTECTION AGENCY REGION 9, Oakland, California. USA, 2008
USEPA, (2009): Municipal Solid Waste Generation, Recycling, and Disposal in the United States Detailed Tables and Figures for 2008. www.epa.gov

Zavodska, A, (2003). A study of residential solid waste composition and management in a selected developing country - Guyana. The Journal of solid waste management and technology,

Department of Civil Engineering Widener University, Chester, U.S.A. 29(1).

Zhang, R., El-Mashad, H.M., Hartman, K., Wang, F., Liu, G., Choate, C., and Gamble, P. (2007). Characterisation of Food waste as feedstock for $A D$. Bioresource Technology, 98: 929-935. 